\title{
Effects of gypenosides on enteroendocrine L-cell function and GLP-1 secretion
}

Chinmai Patibandla, Erin Campbell, Xinhua Shu, Angus M Shaw, Sharron Dolan, Steven Patterson

Department of Biological and Biomedical Sciences, School of Health and Life

Sciences, Glasgow Caledonian University, Cowcaddens road, Glasgow, G4 0BA, United Kingdom.

Corresponding author: Dr Steven Patterson, Ph.D., Department of Biological and Biomedical sciences, School of Health and Life Sciences, Glasgow Caledonian University, Cowcaddens road, Glasgow, G4 0BA, United Kingdom.

Email: steven.patterson@gcu.ac.uk,Tel: +441413313156.

\section{Authors' email addresses:}

Chinmai Patibandla (cpatib10@gcu.ac.uk);

Erin Campbell (ecampb205@caledonian.ac.uk);

Xinhua Shu (Xinhua.Shu@gcu.ac.uk);

Angus M Shaw (angusmshaw65@gmail.com);

Sharron Dolan (sharron.dolan@gcu.ac.uk); 


\section{Abstract}

Glucagon-like peptide 1 (GLP-1) is an incretin hormone produced in gut L-cells, which regulates postprandial glucose-dependent insulin secretion, also known as the incretin effect. GLP-1 secretion may be reduced in type 2 diabetes mellitus, impacting on glycaemic regulation. Thus, methods to enhance endogenous GLP-1 secretion by use of natural GLP-1 secretagogues may improve glucose control in diabetes. Gypenosides (GYP) extracted from the plant Gynostemma Pentaphyllum (Jiaogulan) are known for their glucose-lowering effects both in vitro and in vivo, although their effect on GLP-1 secretion is unknown. Our results showed that GYP enhanced cell viability and significantly upregulated antioxidant gene Nrf2, Cat and Ho-1 expression. GYP did not affect glucokinase expression but downregulated proglucagon gene expression over $24 \mathrm{~h}$, although, cellular GLP-1 content was unchanged. Prohormone convertase 1 (Pcsk1) gene expression was unchanged by GYP over $24 \mathrm{~h}$, although protein levels were significantly downregulated, while prohormone convertase 2 (Pcsk2) mRNA and protein levels were significantly upregulated. Acute exposure to gypenosides enhanced calcium uptake and GLP-1 release from GLUTag cells both at low and high glucose concentrations. These results suggest that anti-diabetic properties of gypenosides are partly linked to their ability to stimulate GLP-1 secretion. Gypenosides enhance antioxidant gene expression and may protect L-cells from excess oxidative stress. 
Key Words: Gypenosides; GLP-1; L-cell; GLUTag; Ncx; Nrf2;

Abbreviations: GLP-1, Glucagon-like peptide-1; GYP,Gypenosides; T2DM,Type 2 diabetes mellitus; Ncx, Sodium/Calcium exchange channel; Sglt1, Sodium/glucose cotransporter 1; Gcg, Glucagon; Gck, Glucokinase; Pc1, Prohormone convertase-1; Pc2, Prohormone convertase-2; Nrf2, Nuclear factor erythroid 2-related factor 2; NFkb1, Nuclear factor Kappa b1; Cat, Catalase; Ho-1, Heme oxygenase-1; MTT, 3(4,5-Dimethylthiazol-2-yl)-2,5-diphenyltetrazolium bromide; 


\section{Introduction}

Glucagon-like peptide-1 (GLP-1) is an intestinal hormone secreted by enteroendocrine L-cells. The proglucagon gene is expressed in L-cells as well as pancreatic alpha cells, and post-translational cleavage by prohormone convertase-1 (Pcsk1) gives rise to peptides glicentin, oxyntomodulin, GLP-1 and GLP-2 (Dhanvantari et al., 1996; Rouillé et al., 1995). Secreted GLP-1 (1-37) exists in two bioactive forms, GLP-1 (7-36), GLP1 (7-37) amide but is rapidly degraded by dipeptidyl peptidase-IV (DPP-IV) to GLP-1 (9-36) and GLP-1 (9-37) amide (Hansen et al., 1999). Active GLP-1 has many systemic functions including, glucose homeostasis by promoting glucosedependent postprandial insulin secretion from pancreatic $\beta$-cells, enhancing insulin gene expression, $\beta$-cell proliferation, activating protective anti-apoptotic pathways and inhibiting the release of glucagon from islet a-cells (Drucker, 2006). It has been reported that GLP-1 secretion is reduced along with the impairment of the incretin effect in type 2 diabetes mellitus (T2DM) (Mannucci et al., 2000).

Hyperglycaemic- and hyperlipidaemic-induced pancreatic $\quad \beta$-cell oxidative stress and apoptosis in T2DM has been well studied in vivo and in vitro but similar studies in L-cells are scarce due to their location and distribution in the gut. Previous studies in L-cell model (GLUTag cells) showed that chronic exposure to palmitate and glucose, significantly reduced cell viability (Vasu et al., 2015), and altered proglucagon gene processing (Hayashi et al., 2014), indicating that hyperglycemia and hyperlipidaemia might also have a detrimental effect on Lcells and perhaps contribute to impaired incretin responses. Activation of the Nrf2 antioxidant pathway has significant protective effects against oxidative stress in pancreatic $\beta$-cells (Abebe et al., 2017; Masuda et al., 2015). A similar Nrf2 mediated 
protective effect may also protect L-cells exposed to prolonged stress. Thus, any pharmacological agents stimulating endogenous GLP-1 secretion from gut L-cells that also possess antioxidant mediated cell protection could prove beneficial in the management of T2DM.

Gynostemma pentaphyllum (GP) Makino, also known as Jiaogulan, grows in several parts of Asia (China, Japan, Vietnam, India and Korea) and has been used in Chinese folk medicine for centuries due to its proposed wide-ranging health benefits. Antidiabetic properties of GYP are well documented both in T2DM patients and diabetic rodent models. While the majority of previous studies on the anti-diabetic properties of GYP have focused on $\beta$-cells and insulin secretion, hepatic glucose output (Yassin et al., 2011) and adipose insulin sensitivity (Liu et al., 2017), its effect on gut endocrine function, specifically GLP-1 secreting L-cells has yet to be investigated. Thus the current study is focused on investigating GYP effects on GLP1 secretion and L-cell function using the robustly characterised mouse intestinal L-cell model, GLUTag cell line (Drucker et al., 1994; Kuhre et al., 2016). 


\section{Methods}

\subsection{Cell Culture and viability}

GLUTag cells (a kind gift from Prof. D Drucker) were routinely cultured in Dulbecco's modified eagle medium (DMEM) (5.5 mmol/L D-glucose) (Lonza, UK), supplemented with $10 \%(\mathrm{v} / \mathrm{v})$ foetal bovine serum $(\mathrm{v} / \mathrm{v}), 50 \mathrm{U} / \mathrm{ml}$ penicillin/streptomycin and $2 \mathrm{mM} \mathrm{L-}$ glutamine, and were maintained at $37^{\circ} \mathrm{C}$ with $5 \% \mathrm{CO}_{2}$ and $95 \%$ air (Drucker et al., 1992; Lee et al., 1992). Cells were trypsinised and sub-cultured at 1:5 dilutions when $80-90 \%$ confluence was reached. Passage numbers from 25 to 35 were used for experiments. To determine the effects of CPE on cell viability over $24 \mathrm{~h}$, GLUTag cells were seeded in Geltrex $^{\mathrm{TM}}$ (Gibco, UK) coated 96 well plates at 10,000 cells/well. After overnight culture, cells were incubated with CPE $(0.78$ to $200 \mu \mathrm{g} / \mathrm{ml})$ for $24 \mathrm{~h}$ and cell viability assessed using MTT assay.

MIN6 cells were cultured in DMEM containing 4.5g/L glucose supplemented with $10 \%$ FBS (v/v) and $50 \mathrm{U} / \mathrm{ml}$ penicillin/streptomycin. Cells were maintained at $37^{\circ} \mathrm{C}$ with $5 \%$ $\mathrm{CO}_{2}$ and $95 \%$ air. When $80-90 \%$ confluence was reached, cells were detached from the flask using trypsin/EDTA and sub-cultured at 1:3 dilution.

\subsection{GYP Extract}

Gypenosides were purchased from Xi'an Jiatian Biotech Co. Ltd, China (purity 98\%). Gypenosides were dissolved in absolute ethanol $(25 \mathrm{mg} / \mathrm{ml})$ by continuous shaking at room temperature overnight and stored at $-20^{\circ} \mathrm{C}$ until use. 


\section{$2.3 \mathrm{Ca}^{2+}$ measurement}

GLUTag cells were seeded on Geltrex ${ }^{\mathrm{TM}}$ coated glass coverslips and cultured until confluent. Prior to use, cells were incubated for 45 min with $2 \mu \mathrm{M}$ FURA-2AM (Tocris, UK) in KRB Buffer containing $1.1 \mathrm{mM}$ glucose at $37^{\circ} \mathrm{C}$. The $\mathrm{KRB}$ buffer was composed of (in mmol/L): $115 \mathrm{NaCl}, 4.7 \mathrm{KCl}, 1.2 \mathrm{KH}_{2} \mathrm{PO}_{4}, 1.2 \mathrm{MgSO}_{4}, 1.28 \mathrm{CaCl}_{2}, 20$ HEPES and $0.1 \%(\mathrm{w} / \mathrm{v})$ BSA ( $\mathrm{pH} 7.4)$. Coverslips were rinsed with PBS and mounted onto an RC-21BRW closed bath imaging chamber (Warner Instruments) with P-2 platform and cells were perfused at a rate of $1 \mathrm{ml} / \mathrm{min}$ with $\mathrm{KRB}$ Buffer with/without GYP. A Nikon Eclipse TE2000-U microscope fitted with Photometrics Cool SNAPTM HQ Camera was used to acquire images. Fluorescence emission was recorded and cytosolic $\mathrm{Ca}^{2+}$ changes were plotted as $340 \mathrm{~nm} / 380 \mathrm{~nm}$ ratio over time.

\subsection{Measurement of GLP-1 Secretion by ELISA}

For secretion tests, cells were seeded on 12 well plates $\left(2.5 \times 10^{5}\right.$ cells/well $)$ coated with Geltrex ${ }^{\mathrm{TM}}$ and incubated for $24 \mathrm{~h}$. Prior to use, cells were washed and incubated for 30 mins with KRB Buffer (1.1mM Glucose) followed by $1 \mathrm{~h}$ incubation with test reagents. The supernatant was collected and centrifuged at $900 \mathrm{~g}$ for $5 \mathrm{mins}$ and GLP1 secretion over $1 \mathrm{~h}$ treatment with GYP was measured using a total GLP-1 ELISA kit (Millipore, UK) according to manufacturer's specifications.

\subsection{Immunofluorescence}

To analyse GLP-1 staining, GLUTag cells (1X105 cells/ coverslip) were seeded on Geltrex ${ }^{\mathrm{TM}}$ coated glass coverslips and cultured overnight until confluent. After 
treatment with $100 \mu \mathrm{g} / \mathrm{ml}$ GYP for $24 \mathrm{~h}$, cells were fixed with $4 \%$ paraformaldehyde for 10 mins at $4^{\circ} \mathrm{C}$ followed by 30 mins blocking with $2 \%$ BSA and stained with anti-GLP1 antibody (1:200) (Gt pAb to GLP-1, SC-26637, Santa Cruz Biotechnology) overnight in a humid chamber at $4^{\circ} \mathrm{C}$. The secondary antibody was added and incubated at room temperature for $1 \mathrm{~h}$ (Alexafluor 594 donkey anti-goat IgG secondary antibody (1:500) Abcam, ab150132). Mounting medium with DAPI (Abcam, ab104139) was used to stain the nucleus and slides were visualised and images were captured using EVOS FL imaging system.

\subsection{RNA extraction and PCR}

Total RNA was extracted from GYP treated GLUTag cells using the NucleoSpin® RNA kit (Macherey-Nagel, UK) according to the manufacturer's protocol. From total RNA, cDNA was synthesised using High-Capacity cDNA reverse transcription kit (Applied Biosystems, UK). Using mouse Ncx1, Ncx2 and Ncx3 specific primers, cDNA was amplified by PCR using 5x FIREPo| $囚$ Master Mix (Solis-BioDyne, Estonia) and $\beta$ Actin was used as the housekeeping gene. Cycling conditions were; initial denaturation at $95^{\circ} \mathrm{C}$ for 4 mins followed by 40 cycles of $95^{\circ} \mathrm{C}$ for $20 \mathrm{sec}, 54^{\circ} \mathrm{C}$ for 45 sec, $72^{\circ} \mathrm{C}$ for $45 \mathrm{sec}$; and final elongation was at $72^{\circ} \mathrm{C}$ for 5 mins. Primers used are Ncx1,F- CCTTGTGCATCTTAGCAATG, R- TCTCACTCATCTCCACCAGA; Ncx2, F- CACGCACCTTCCCTGATTTA, R- CTCATCCACTAAGCTGGTTCTC; Ncx3, F- CTATCCCACCACCCAACTATTC, R- GTCAGCCTGGAACACTCTTATC; which yielded product sizes of $437 \mathrm{bp}, 316 \mathrm{bp}$ and $482 \mathrm{bp}$, respectively. PCR products were separated by $2 \%$ agarose gels and visualised by Midori green (Geneflow, UK). 


\subsection{Quantitative real-time PCR}

Quantitative real-time PCR was performed on a CFX96 ${ }^{\mathrm{TM}}$ Real-Time PCR detection system using $\mathrm{iQ}^{\mathrm{TM}} \quad \mathrm{SYBR} \otimes$ Green Supermix (BIO-RAD, UK) according to manufacturer's specifications. Primer sequences used were listed in table 1.

\begin{tabular}{|c|c|c|c|c|}
\hline Gene & & Primer Sequence & $\begin{array}{c}\text { Prod } \\
\text { uct } \\
\text { Size } \\
\text { (bp) }\end{array}$ & $\begin{array}{c}\text { Accession } \\
\text { number }\end{array}$ \\
\hline \multirow{2}{*}{ Actb } & $\mathrm{F}$ & AGTGTGACGTTGACATCCGT & \multirow{2}{*}{120} & \multirow{2}{*}{ NM_007393.5 } \\
\hline & $\mathrm{R}$ & TGCTAGGAGCCAGAGCAGTA & & \\
\hline \multirow{2}{*}{$\begin{array}{c}\text { Nrf2/ } \\
\text { Nfe2l2 }\end{array}$} & $\mathrm{F}$ & TTTTCCATTCCCGAATTACAGT & \multirow{2}{*}{130} & \multirow{2}{*}{ NM_010902.4 } \\
\hline & $\mathrm{R}$ & AGGAGATCGATGAGTAAAAATGGT & & \\
\hline \multirow{2}{*}{$\begin{array}{c}\text { Ho1/ } \\
\text { Hmox1 }\end{array}$} & $\mathrm{F}$ & CAGAAGAGGCTAAGACCGCCTT & \multirow{2}{*}{87} & \multirow{2}{*}{ NM_010442.2 } \\
\hline & $\mathrm{R}$ & TCTGGTCTTTGTGTTCCTCTGTCA & & \\
\hline \multirow{2}{*}{ Catalase } & $\mathrm{F}$ & CCTCGTTCAGGATGTGGTTT & \multirow{2}{*}{121} & \multirow{2}{*}{ NM_009804.2 } \\
\hline & $\mathrm{R}$ & ATCGTGGGTGACCTCAAAGT & & \\
\hline \multirow{2}{*}{ Gcg } & $\mathrm{F}$ & AGCGACTACAGCAAATACCTG & \multirow{2}{*}{146} & \multirow{2}{*}{ NM_008100.4 } \\
\hline & $\mathrm{R}$ & CTCACATCACTGGTAAAGGTCC & & \\
\hline \multirow{2}{*}{ Gck } & $\mathrm{F}$ & СTTCACСТTСТССТTCCСTG & \multirow{2}{*}{150} & \multirow{2}{*}{ NM_010292.5 } \\
\hline & $\mathrm{R}$ & ATCTCAAAGTCСССТСТССТ & & \\
\hline \multirow{2}{*}{ Pcsk1 } & $\mathrm{F}$ & GTACACATCCTACAATACAGTCCAG & \multirow{2}{*}{150} & \multirow{2}{*}{ NM_013628.2 } \\
\hline & $\mathrm{R}$ & TCCСTTCTACCCTCCACATT & & \\
\hline \multirow{2}{*}{ Pcsk2 } & $\mathrm{F}$ & CCGAGGAGGAGCTGAAAATGCAGAT & \multirow{2}{*}{104} & \multirow{2}{*}{ NM_008792.4 } \\
\hline & $\mathrm{R}$ & CTGGCTGGCAGGGGTGCGAAT & & \\
\hline \multirow{2}{*}{ Pde3b } & $\mathrm{F}$ & TCACAAGGGATTGAGTGGCA & \multirow{2}{*}{108} & \multirow{2}{*}{ NM_011055.2 } \\
\hline & $\mathrm{R}$ & CTGCGATCCCACCTTGAACA & & \\
\hline \multirow{2}{*}{$\begin{array}{l}\text { Ncx1/ } \\
\text { Slc8a1 }\end{array}$} & $\mathrm{F}$ & TTTGCCTTCGTCCCACCTAC & \multirow{2}{*}{73} & \multirow{2}{*}{ NM_001112798.2 } \\
\hline & $\mathrm{R}$ & GGCCGATCATGAGGATGGAG & & \\
\hline \multirow{2}{*}{$\begin{array}{l}\text { Sglt1/ } \\
\text { Slc5a1 }\end{array}$} & $\mathrm{F}$ & CTTTGAATGGAACGCCTTGG & \multirow{2}{*}{148} & \multirow{2}{*}{ NM_019810.4 } \\
\hline & $\mathrm{R}$ & GGACAGAACGGAAAGGTAGATC & & \\
\hline
\end{tabular}

Table 1: List of mouse primers used in the quantitative real-time PCR 


\subsection{Western blot}

Cells were lysed with ice-cold radioimmunoassay precipitation buffer (RIPA) (50mM Tris- $\mathrm{HCl} \mathrm{pH} 8.0,150 \mathrm{mM} \mathrm{NaCl}, 1 \% \mathrm{NP}-40,0.5 \%$ sodium deoxycholate, $0.1 \%$ sodium dodecyl sulphate) and centrifuged at 10,000 rpm for $15 \mathrm{mins}\left(4^{\circ} \mathrm{C}\right)$ to separate any cell debris. Protein concentration in the supernatant was measured using DC ${ }^{\mathrm{TM}}$ Protein assay kit (BIO-RAD, UK) according to manufacturer's specifications using bovine serum albumin (BSA) as standard. Proteins were separated by SDS-PAGE using hand cast gradient gels $(4-12 \%)$ and transferred to nitrocellulose membrane (20V for 10mins) using the iBlot $®$ blotting system (Thermo Scientific, UK). Membranes were blocked with $5 \%(\mathrm{w} / \mathrm{v})$ BSA for $1 \mathrm{~h}$ at room temperature and incubated with primary antibodies overnight at $4^{\circ} \mathrm{C}$. Primary antibodies used were: Anti-Pcsk1 (1:1000)

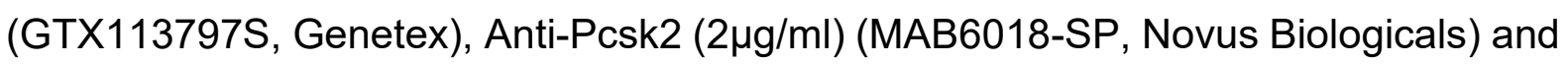
Anti-Actin-beta (1:1000) (ab-1801, Abcam UK). Blots were incubated with IRDye ${ }^{\circledR}$ conjugated specific secondary antibodies (1:5000) for $1 \mathrm{~h}$ at room temperature. Signals were detected using the Odyssey® Fc imaging system (LI-COR, UK) and analysed using Image Studio ${ }^{\mathrm{TM}}$ software.

\subsection{Data Analysis}

Results were presented as means \pm S.E.M. Data were analysed in Graphpad PRISM® software (ver 6.01) by using unpaired student's t-test (parametric, two-tailed) for comparing two groups or one-way ANOVA for comparing more than 2 groups with Dunnett's post hoc test with a significance threshold of $p<0.05$. 


\section{Results}

\subsection{Effects of GYP on GLUTag cell viability}

To elucidate the effect of GYP extract on GLUTag cell viability, cells were incubated for $24 \mathrm{~h}$ with different concentrations $(3.125 \mu \mathrm{g} / \mathrm{ml}-200 \mu \mathrm{g} / \mathrm{ml})$ of GYP and an MTT assay performed to assess the cell viability. At high concentration of $200 \mu \mathrm{g} / \mathrm{ml}$ GYP significantly reduced cell viability $(p<0.0001)$ by $36.4 \%$ (Fig.1). Lower concentration of 100,50 and $25 \mu \mathrm{g} / \mathrm{ml}$ enhanced GLUTag viability compared to control (for $100 \& 50 \mu \mathrm{g} / \mathrm{ml} P<0.0001$; for $25 \mu \mathrm{g} / \mathrm{ml}$ $P<0.05)$ (fig.1)

\subsection{Effects of GYP on GLP-1 release and intracellular calcium $\left[\mathrm{Ca}^{2+}\right]_{\mathrm{i}}$}

GYP treatment over $1 \mathrm{~h}$ concentration-dependently stimulated GLP-1 secretion from GLUTag cells both at low $(1.1 \mathrm{mM})$ and high $(16.7 \mathrm{mM})$ glucose concentrations (Fig 2A). At low glucose concentration, $50 \& 100 \mu \mathrm{g} / \mathrm{ml}$ GYP increased GLP-1 release 2.7$(P<0.05)$ and 7.5-fold $(P<0.0001)$, respectively. At high glucose, these concentrations elicited 3.6- $(P<0.001)$ and 13.5-fold $(P<0.01)$ increases in GLP-1 release compared to high glucose alone. There was no significant difference in GLP-1 secretion between low compared to high glucose for any GYP concentration.

As for all endocrine secretory cells, intracellular calcium levels play a fundamental role in GLP-1 exocytosis. GLUTag cells were perfused with GYP in the presence of low and high glucose concentrations. In response to acute exposure to GYP $(100 \mu \mathrm{g} / \mathrm{ml}), \quad\left[\mathrm{Ca}^{2+}\right]$ iwas increased at both low $(1.1 \mathrm{mM})$ and high (16.7mM) glucose concentrations, as shown in Figure 2B. 


\subsection{Effects of GYP treatment on L-cell gene expression}

Pro-inflammatory transcription factor, nuclear factor -kappa-B p105 (Nfkb1) was unchanged after 24h GYP treatment, whereas Nuclear Factor, Erythroid 2 Like 2 (Nfe2l2 / Nrf2), heme oxygenase 1 (Hmox1/ Ho1) $(\mathrm{P}<0.001)$ and catalase (Cat) expression were all increased by GYP $(P<0.001$ - 0.0001) (Fig. 4.5A). GYP treatment $(100 \mu \mathrm{g} / \mathrm{ml})$ over $24 \mathrm{~h}$ significantly downregulated proglucagon $(\mathrm{Gcg})(\mathrm{P}<0.001)$ gene expression in GLUTag cells, although glucokinase (Gck) and prohormone convertase 1 (Pcsk1) expression were unchanged (Fig. 4.5B). Interestingly, prohormone convertase 2 expression was enhanced $(P<0.0001)$ following $24 \mathrm{~h}$ GYP treatment. Expression of the main regulator of glucose uptake in L-cells, the sodium/glucose cotransporter-1 (Sglt-1/ Slc5a1), was also upregulated $(P<0.0001)$ along with sodium/calcium exchanger Ncx1 $(P<0.05)$ (Fig. 4.5C).

\subsection{Expression of Ncx isoforms in GLUTag cells}

Although GYP induced a significant increase in Ncx 1 expression, it has not previously been confirmed which other Ncx isoforms are expressed in GLUTag cells. RT-PCR was performed followed by gel electrophoresis to identify the Ncx isoforms. PCR product identity was confirmed by sequencing, confirming the expression of all three isoforms of Ncx (Ncx1, Ncx2 and Ncx3) in GLUTag L-cells (Fig.4). We have used mouse $\beta$-cell line MIN6 cell cDNA as a positive control as it is previously known that Ncx isoforms are expressed in pancreatic $\beta$-cells (Fig. 4). 


\subsection{Effects of GYP on Protein expression and GLP-1 staining}

At a concentration of $100 \mu \mathrm{g} / \mathrm{ml}$, GYP treatment over $24 \mathrm{~h}$ enhanced Pcsk2 $(P<0.05)$ and downregulated Pcsk1 $(\mathrm{P}<0.01)$ protein levels (Fig.5). As 24h treatment with GYP downregulated proglucagon expression and Pcsk1 protein levels, we analysed the possible changes in staining intensity of cellular GLP-1 by immunostaining and the results showed no significant difference (Fig. 6). 


\section{Discussion}

GLP-1 secreting L-cells are mostly concentrated along the distal part of the ileum and terminal colon. They are open-type intestinal epithelial cells that have contact with luminal nutrients via their apical surface while their basolateral surface is connected to underlying neural and vascular tissue (Baggio and Drucker, 2007). Both primary Lcells and the murine GLUTag L-cell model express sodium-glucose cotransporters 1 and 3 (Sglt1 and Sglt3) which co-transports two sodium ions with every molecule of glucose (Gribble et al., 2003; Reimann and Gribble, 2002). Previous studies in perfused rat small intestine and GLUTag cells confirmed that blocking Sglt1 completely abolished glucose-induced GLP-1 secretion (Gribble et al., 2003). A similarly impaired secretion was observed in perfused rat intestine when luminal $\mathrm{Na}^{+}$was deprived, indicating $\mathrm{Na}^{+}$coupled glucose uptake is necessary for GLP-1 secretion (Kuhre et al., 2015). The events following elevated intracellular $\mathrm{Na}^{+}$via Sglt1 and GLP-1 secretion are not fully understood. It is believed that sodium/calcium exchangers (Ncx) play an important role in $\mathrm{Na}^{+}$and $\mathrm{Ca}^{2+}$ homeostasis. The $\mathrm{Ncx}$ family exists in three subtypes Ncx1-3 encoded by Slc8a1-3 genes and they can operate either in the forward mode $\left(\mathrm{Na}^{+}\right.$entry and $\mathrm{Ca}^{2+}$ exit) or reverse mode ( $\mathrm{Na}^{+}$exit and $\mathrm{Ca}^{2+}$ entry) (Dong et al., 2005). Intestinal basal epithelial cells of small intestine, colon and rectum express Ncx1. Previous reports have shown that Vitamin D enhances Ncx1 gene expression and regulates transmembrane $\mathrm{Ca}^{2+}$ transport (Liao et al., 2019). In duodenal mucosal epithelium, bicarbonate secretion was regulated by Ncx1 reverse mode activation (Dong et al., 2005). A rat small intestinal epithelial cell line (IEC-18) expressing both Sglt1 and sodium/calcium exchanger family (Ncx1) has been shown to regulate intracellular sodium and calcium levels via activation of Ncx1 (Chen et al., 2016). Perhaps a similar mechanism might help in 
maintaining L-cell membrane potential. In the present study, we have confirmed the gene expression of all three Ncx family subtypes Ncx1, Ncx2 and Ncx3 in GLUTag cells, although expression at the protein level was not investigated. However, the potential role of Ncx in sodium/calcium homeostasis and GLP-1 secretion in L-cells is yet to be established. In the present study, GYP stimulated calcium uptake acutely at both low and high glucose concentrations along with mRNA levels of both Sglt1 and Ncx1 indicating GYP might regulate intracellular $\mathrm{Na}^{+}$and $\mathrm{Ca}^{2+}$ homeostasis in the GLUTag cells. Consistent with these calcium observations, GYP acutely enhanced GLP-1 secretion from GLUTag cells concentration-dependently, irrespective of glucose concentration. While these observations are limited to GLUTag cells in the current study, further investigation using primary L-cells isolated from human or animal models is warranted to establish the potential translation of these interesting findings. In pancreatic $\beta$-cells, gluco- and lipo-toxicity increase ROS generation and induces oxidative stress which can lead to cellular dysfunction and demise. Due to the very low expression of antioxidant enzymes which are necessary for neutralising ROS, oxidative stress causes $\beta$-cell apoptosis (Vasu et al., 2015). Similar results were observed in GLUTag cells when exposed to elevated levels of glucose and fatty acid to induce cytotoxicity (Vasu et al., 2015). Under conditions of oxidative stress, activation of the Nrf2/Keap1/ARE pathway is upregulated to enhance endogenous antioxidants which are necessary for free radical scavenging and cellular protection. Activation of superoxide dismutase genes (SOD1 and SOD2) by Nrf2 regulates intracellular superoxide levels by converting them to hydrogen peroxide, and Nrf2 mediated upregulation of catalase and glutathione peroxidase genes prevent hydrogen peroxide accumulation by converting it into water molecules (Pall and Levine, 2015). Ho-1 is another cytoprotective gene regulated by Nrf2 (Alam et al., 
1999). It can be stimulated by several stimuli including cytokines, nitric oxide, heme, modified lipids and growth factors, and it acts to catalyse heme degradation to generate iron ion, biliverdin and carbon monoxide $(\mathrm{CO})$, which are known for antiapoptotic, anti-oxidant and anti-inflammatory properties (Loboda et al., 2016). In previous studies, Nrf2 activation promoted $\beta$-cell self-repair after high fat diet induced oxidative stress in rats (Abebe et al., 2017). The activators of Nrf2 have been shown to improve insulin sensitivity in mice and to protect against ROS and cytokine toxicity in human islet cells (Masuda et al., 2015; Yu et al., 2011). The role of Nrf2 pathway in $\beta$-cell protection is well characterised, although its function in intestinal L-cells is yet to be investigated.

In previous studies, GYP protected PC12 cells (a model of neuronal differentiation) from amyloid-beta induced apoptosis by activating Nrf2 pathway (Meng et al., 2014). Similar Nrf2 mediated protective effects against peroxide-induced toxicity have been reported in retinal epithelial cells (Alhasani et al., 2018). GYP treatment in a streptozotocin-induced diabetic rat model significantly upregulated Nrf2 expression and protected against oxidative stress (Gao et al., 2016). In agreement with these results, we have observed an increase in GLUTag cell viability following GYP treatment for $24 \mathrm{~h}$ with upregulation of Nrf2 expression also noted in these cells along with upregulation of antioxidant Cat and Ho1 expression. Thus, GYP by upregulation of these antioxidant molecules in GLUTag cells may enable protection of the cells against increased cellular peroxide levels as may be observed under lipo and glucotoxic conditions. The importance of this in in vivo, given the turnover of gut endocrine cells, requires further investigation in normal and obese/diabetes models.

The proglucagon gene is expressed in both intestinal L-cells and pancreatic $\alpha$ cells, with post-translational processing of the propeptide by Pcsk1 generating GLP-1 
in L-cells and Pcsk2 producing glucagon in a-cells (Drucker, 2006). It is known that the gut also produces extrapancreatic glucagon in humans (Lund et al., 2016). There is enough evidence that L-cells express and produce glucagon under specific conditions (Filippello et al., 2018; Kuhre et al., 2016). Chronic exposure to saturated free fatty acid palmitate caused increased glucagon and Pcsk2 expression, reduced Pcsk1 expression and GLP-1 secretion and might play a role in shifting L-cells towards glucagon production promoting glycaemic dysregulation (Filippello et al., 2018).

In this study, we found that acute exposure of GLUTag cells to GYP enhanced GLP1 secretion irrespective of glucose concentration. However, prolonged $24 \mathrm{~h}$ exposure of GLUTag cells to GYP resulted in a reduction in proglucagon mRNA, Pcsk1 protein levels and enhanced Pcsk2 mRNA and protein level. Although the mechanism underlying this reduction is unclear, it is not uncommon for reduced proglucagon expression following perhaps prolonged stimulation of GLP-1 secretion. A study by Lindqvist et al., (2017) showed that stimulatory concentrations of ghrelin enhanced GLP-1 secretion from GLUTag cells acutely yet following $24 \mathrm{~h}$ treatment reduced proglucagon expression levels. While we noted a reduction in proglucagon gene expression, cellular staining intensity for GLP-1 did not appear to be reduced perhaps due to reserve GLP-1 granule pools, but this requires further investigation and quantification of GLP-1 content by ELISA.

\section{Conclusion:}

GLUTag cells express all 3 Ncx family ion channels and GYP treatment enhances Sglt1 and Ncx1 mRNA levels. Acutely, GYP induced calcium uptake and enhanced GLP-1 secretion from GLUTag cells irrespective of glucose 
concentration, while longer exposure of GLUTag cells to GYP downregulates proglucagon mRNA levels and up-regulates Pcsk2, although Pcsk1 mRNA and GLP-

1 content were unchanged. Nrf2, Ho1 and Cat mRNA levels were upregulated in GLUTag cells following GYP treatment and enhanced cell viability. Further studies are required to confirm these results in primary L-cells and in vivo but suggest that GYP may modulate and enhance GLP-1 secretion acutely and protect cells against metabolic stress observed in obesity and diabetes.

\section{Conflict of interest:}

The authors declare no conflict of interest.

\section{Funding:}

This research is partly funded by The Rosetrees trust, UK grant CM160. 


\section{References:}

Abebe, T., Mahadevan, J., Bogachus, L., Hahn, S., Black, M., Oseid, E., Urano, F., Cirulli, V., Robertson, R.P., 2017. Nrf2/antioxidant pathway mediates $\beta$ cell self-repair after damage by high-fat diet-induced oxidative stress. $\mathrm{JCl}$ insight 2, e92854. https://doi.org/10.1172/jci.insight.92854

Alam, J., Stewart, D., Touchard, C., Boinapally, S., Choi, A.M., Cook, J.L., 1999. Nrf2, a Cap'n'Collar transcription factor, regulates induction of the heme oxygenase-1 gene. J. Biol. Chem. 274, 26071-8. https://doi.org/10.1074/jbc.274.37.26071

Alhasani, R.H., Biswas, L., Tohari, A.M., Zhou, X., Reilly, J., He, J.-F., Shu, X., 2018. Gypenosides protect retinal pigment epithelium cells from oxidative stress. Food Chem. Toxicol. 112, 76-85. https://doi.org/10.1016/j.fct.2017.12.037

Baggio, L.L., Drucker, D.J., 2007. Biology of Incretins: GLP-1 and GIP. Gastroenterology 132, 2131-2157. https://doi.org/10.1053/j.gastro.2007.03.054

Chen, L., Tuo, B., Dong, H., 2016. Regulation of Intestinal Glucose Absorption by lon Channels and Transporters. Nutrients 8, 43. https://doi.org/10.3390/nu8010043

Dhanvantari, S., Seidah, N.G., Brubaker, P.L., 1996. Role of Prohormone Convertases in the Tissue-Specific Processing of Proglucagon. Mol. Endocrinol. 10, 342-355. https://doi.org/10.1210/mend.10.4.8721980

Dong, H., Sellers, Z.M., Smith, A., Chow, J.Y.C., Barrett, K.E., 2005. Na(+)/Ca(2+) exchange regulates $\mathrm{Ca}(2+)$-dependent duodenal mucosal ion transport and $\mathrm{HCO}(3)(-)$ secretion in mice. Am. J. Physiol. Gastrointest. Liver Physiol. 288, G457-65. https://doi.org/10.1152/ajpgi.00381.2004

Drucker, D.J., 2006. The biology of incretin hormones. Cell Metab. 3, 153-65. https://doi.org/10.1016/j.cmet.2006.01.004 
Drucker, D.J., Jin, T., Asa, S.L., Young, T.A., Brubaker, P.L., 1994. Activation of proglucagon gene transcription by protein kinase-A in a novel mouse enteroendocrine cell line. Mol. Endocrinol. 8, 1646-1655. https://doi.org/10.1210/mend.8.12.7535893

Drucker, D.J., Lee, Y.C., Asa, S.L., Brubaker, P.L., 1992. Inhibition of pancreatic glucagon gene expression in mice bearing a subcutaneous glucagon-producing GLUTag transplantable tumor. Mol. Endocrinol. 6, 2175-2184.

https://doi.org/10.1210/mend.6.12.1491697

Filippello, A., Urbano, F., Di Mauro, S., Scamporrino, A., Di Pino, A., Scicali, R., Rabuazzo, A.M., Purrello, F., Piro, S., 2018. Chronic Exposure to Palmitate Impairs Insulin Signaling in an Intestinal L-cell Line: A Possible Shift from GLP-1 to Glucagon Production. Int. J. Mol. Sci. 19, 3791. https://doi.org/10.3390/ijms19123791

Gao, D., Zhao, M., Qi, X., Liu, Y., Li, N., Liu, Z., Bian, Y., 2016. Hypoglycemic effect of Gynostemma pentaphyllum saponins by enhancing the Nrf2 signaling pathway in STZinducing diabetic rats. Arch. Pharm. Res. 39, 221-230. https://doi.org/10.1007/s12272014-0441-2

Gribble, F.M., Williams, L., Simpson, A.K., Reimann, F., 2003. A novel glucose-sensing mechanism contributing to glucagon-like peptide-1 secretion from the GLUTag cell line. Diabetes 52, 1147-54. https://doi.org/10.2337/diabetes.52.5.1147

Hansen, L., Deacon, C.F., Orskov, C., Holst, J.J., 1999. Glucagon-like peptide-1-(736)amide is transformed to glucagon-like peptide-1-(9-36)amide by dipeptidyl peptidase IV in the capillaries supplying the $L$ cells of the porcine intestine. Endocrinology 140, 5356-63. https://doi.org/10.1210/endo.140.11.7143

Hayashi, H., Yamada, R., Das, S.S., Sato, T., Takahashi, A., Hiratsuka, M., Hirasawa, N., 2014. Glucagon-like peptide-1 production in the GLUTag cell line is impaired by free fatty acids via endoplasmic reticulum stress. Metabolism 63, 800-811. 
https://doi.org/10.1016/j.metabol.2014.02.012

Kuhre, R.E., Frost, C.R., Svendsen, B., Holst, J.J., 2015. Molecular mechanisms of glucosestimulated GLP-1 secretion from perfused rat small intestine. Diabetes 64, 370-82. https://doi.org/10.2337/db14-0807

Kuhre, R.E., Wewer Albrechtsen, N.J., Deacon, C.F., Balk-Møller, E., Rehfeld, J.F., Reimann, F., Gribble, F.M., Holst, J.J., 2016. Peptide production and secretion in GLUTag, NCl-H716, and STC-1 cells: a comparison to native L-cells. J. Mol. Endocrinol. 56, 201-11. https://doi.org/10.1530/JME-15-0293

Lee, Y.C., Asa, S.L., Drucker, D.J., 1992. Glucagon gene 5'-flanking sequences direct expression of simian virus 40 large $\mathrm{T}$ antigen to the intestine, producing carcinoma of the large bowel in transgenic mice. J. Biol. Chem. 267, 10705-8.

Liao, Q.S., Du, Q., Lou, J., Xu, J.Y., Xie, R., 2019. Roles of $\mathrm{Na}+/ \mathrm{Ca} 2+$ exchanger 1 in digestive system physiology and pathophysiology. World J. Gastroenterol. https://doi.org/10.3748/wjg.v25.i3.287

Lim, G.E., Brubaker, P.L., 2006. Glucagon-Like Peptide 1 Secretion by the L-Cell The View From Within. Diabetes 55, S70-S77. https://doi.org/10.2337/db06-S020

Liu, J., Li, Y., Yang, P., Wan, J., Chang, Q., Wang, T.T.Y., Lu, W., Zhang, Y., Wang, Q., Yu, L.L., 2017. Gypenosides Reduced the Risk of Overweight and Insulin Resistance in C57BL/6J Mice through Modulating Adipose Thermogenesis and Gut Microbiota. J. Agric. Food Chem. 65, 9237-9246. https://doi.org/10.1021/acs.jafc.7b03382

Loboda, A., Damulewicz, M., Pyza, E., Jozkowicz, A., Dulak, J., 2016. Role of Nrf2/HO-1 system in development, oxidative stress response and diseases: an evolutionarily conserved mechanism. Cell. Mol. Life Sci. 73, 3221-47. https://doi.org/10.1007/s00018016-2223-0 
Lund, A., Bagger, J.I., Wewer Albrechtsen, N.J., Christensen, M., Grøndahl, M., Hartmann, B., Mathiesen, E.R., Hansen, C.P., Storkholm, J.H., van Hall, G., Rehfeld, J.F., Hornburg, D., Meissner, F., Mann, M., Larsen, S., Holst, J.J., Vilsbøll, T., Knop, F.K., 2016. Evidence of Extrapancreatic Glucagon Secretion in Man. Diabetes 65, 585-97. https://doi.org/10.2337/db15-1541

Mannucci, E., Ognibene, A., Cremasco, F., Bardini, G., Mencucci, A., Pierazzuoli, E., Ciani, S., Fanelli, A., Messeri, G., Rotella, C.M., 2000. Glucagon-like peptide (GLP)-1 and leptin concentrations in obese patients with Type 2 diabetes mellitus. Diabet. Med. 17, 713-9. https://doi.org/10.1046/j.1464-5491.2000.00367.x

Masuda, Y., Vaziri, N.D., Li, S., Le, A., Hajighasemi-Ossareh, M., Robles, L., Foster, C.E., Stamos, M.J., Al-Abodullah, I., Ricordi, C., Ichii, H., 2015. The effect of Nrf2 pathway activation on human pancreatic islet cells. PLoS One 10, e0131012. https://doi.org/10.1371/journal.pone.0131012

Meng, X., Wang, M., Sun, G., Ye, J., Zhou, Y., Dong, X., Wang, T., Lu, S., Sun, X., 2014. Attenuation of A $325-35$-induced parallel autophagic and apoptotic cell death by gypenoside XVII through the estrogen receptor-dependent activation of Nrf2/ARE pathways. Toxicol. Appl. Pharmacol. 279, 63-75. https://doi.org/10.1016/j.taap.2014.03.026

Pall, M.L., Levine, S., 2015. Nrf2, a master regulator of detoxification and also antioxidant, anti-inflammatory and other cytoprotective mechanisms, is raised by health promoting factors. Acta Physiol. Sin. 67, 1-18. https://doi.org/10.13294/j.aps.2015.0001

Reimann, F., Gribble, F.M., 2002. Glucose-sensing in glucagon-like peptide-1-secreting cells. Diabetes 51, 2757-63. https://doi.org/10.2337/diabetes.51.9.2757

Rouillé, Y., Martin, S., Steiner, D.F., 1995. Differential processing of proglucagon by the subtilisin-like prohormone convertases PC2 and PC3 to generate either glucagon or 
glucagon-like peptide. J. Biol. Chem. 270, 26488-96.

https://doi.org/10.1074/jbc.270.44.26488

Vasu, S., Moffett, R.C., McClenaghan, N.H., Flatt, P.R., 2015a. Differential molecular and cellular responses of GLP-1 secreting L-cells and pancreatic alpha cells to glucotoxicity and lipotoxicity. Exp. Cell Res. 336, 100-108.

https://doi.org/10.1016/j.yexcr.2015.05.022

Vasu, S., Moffett, R.C., McClenaghan, N.H., Flatt, P.R., 2015b. Responses of GLP1secreting L-cells to cytotoxicity resemble pancreatic $\beta$-cells but not $\alpha$-cells. J. Mol. Endocrinol. 54, 91-104. https://doi.org/10.1530/JME-14-0214

Yassin, K., Huyen, V.T.T., Hoa, K.N., Ostenson, C.G., 2011. Herbal extract of gynostemma pentaphyllum decreases hepatic glucose output in type 2 diabetic goto-kakizaki rats. Int. J. Biomed. Sci. 7, 131-6.

Yu, Z., Shao, W., Chiang, Y., Foltz, W., Zhang, Z., Ling, W., Fantus, I.G., Jin, T., 2011. Oltipraz upregulates the nuclear factor (erythroid-derived 2)-like 2 [corrected](NRF2) antioxidant system and prevents insulin resistance and obesity induced by a high-fat diet in C57BL/6J mice. Diabetologia 54, 922-34. https://doi.org/10.1007/s00125-0102001-8 


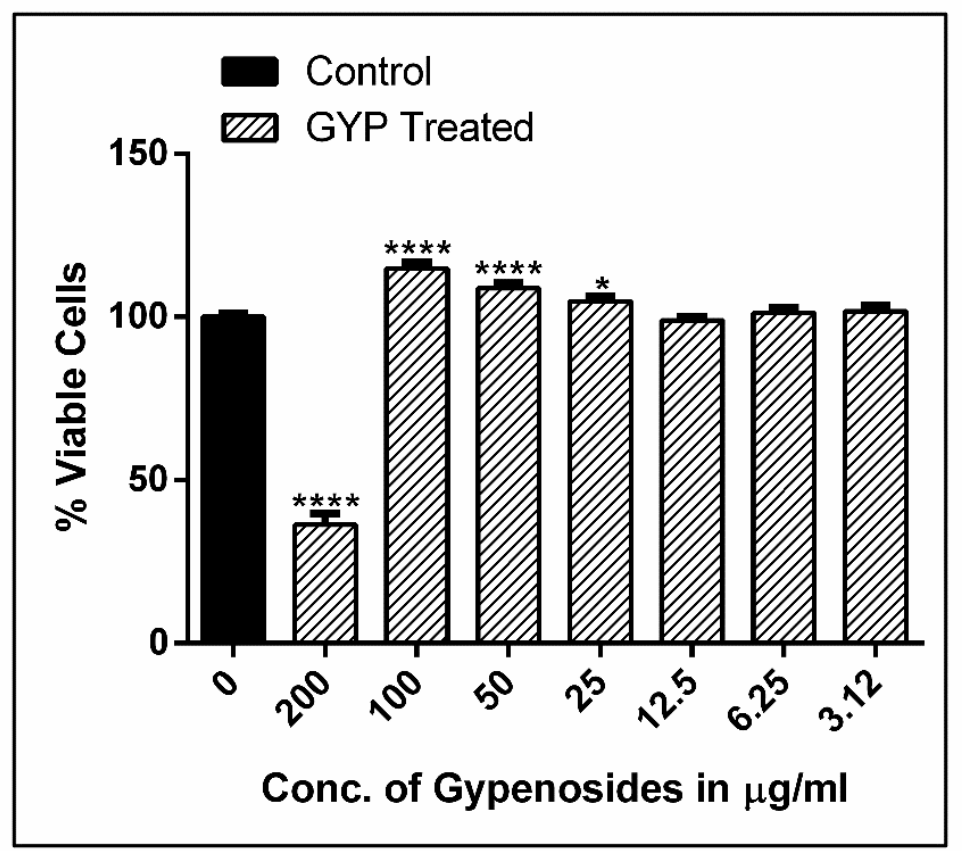

Figure 1: Effects of GYP at concentrations between 3.12 - 200 $\mu \mathrm{g} / \mathrm{ml}$ on GLUTag cell viability over $24 \mathrm{~h}$ treatment. Plotted as \% change in cell viability compared to control. Values represent mean \pm S.E.M. from three different experiments $(n=8)$. Student's $t$ test was used for statistical analysis. *, $\mathrm{P}<0.05 ;{ }^{* * * *}, \mathrm{P}<0.0001$. 


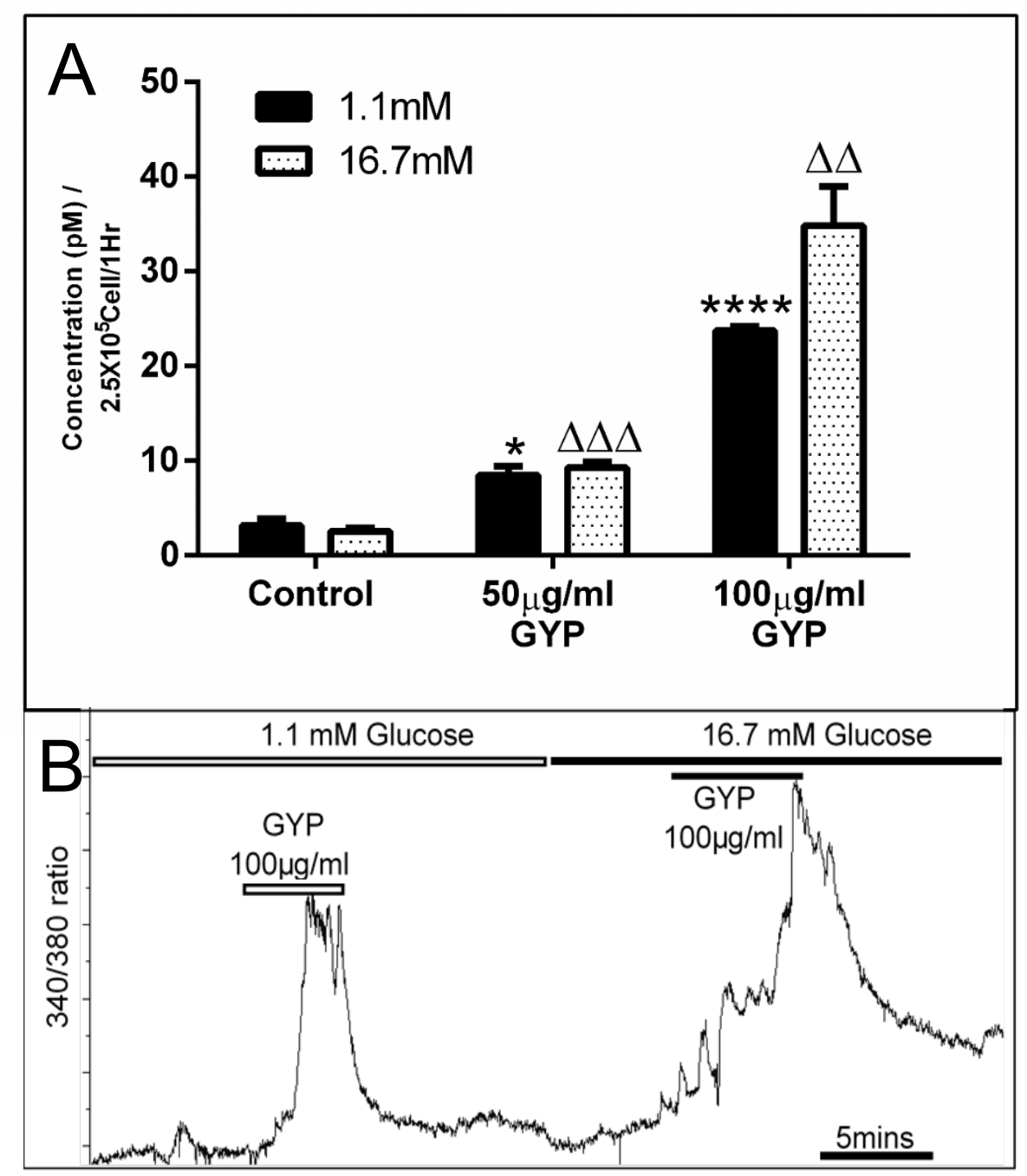

Figure 2: Effects of GYP on GLP-1 secretion and intracellular calcium in GLUTag Lcells. (A) GLP-1 secretion measured in presence of GYP $50 \& 100 \mu \mathrm{g} / \mathrm{ml}$ at low $(1.1 \mathrm{mM})$ (Black) or high $(16.7 \mathrm{mM})$ (dotted) glucose concentration. * , indicates significance compared to $1.1 \mathrm{mM}$ glucose control and $\Delta$, was significance compared to 16.7 glucose control. Values plotted as mean \pm S.E.M. from 4 independent experiments conducted in duplicate. ${ }^{*}, \mathrm{P}<0.05 ;{ }^{* * *}, \mathrm{P}<0.0001 ; \Delta \Delta, \mathrm{P}<0.01$ and $\Delta \Delta \Delta$, $P<0.001$. (B) Changes in intracellular calcium levels in GLUTag cells in presence of $100 \mu \mathrm{g} / \mathrm{ml}$ GYP at low (1.1mM) and high (16.7) glucose concentration. Response was representative of 44 cells from 3 independent experiments. 


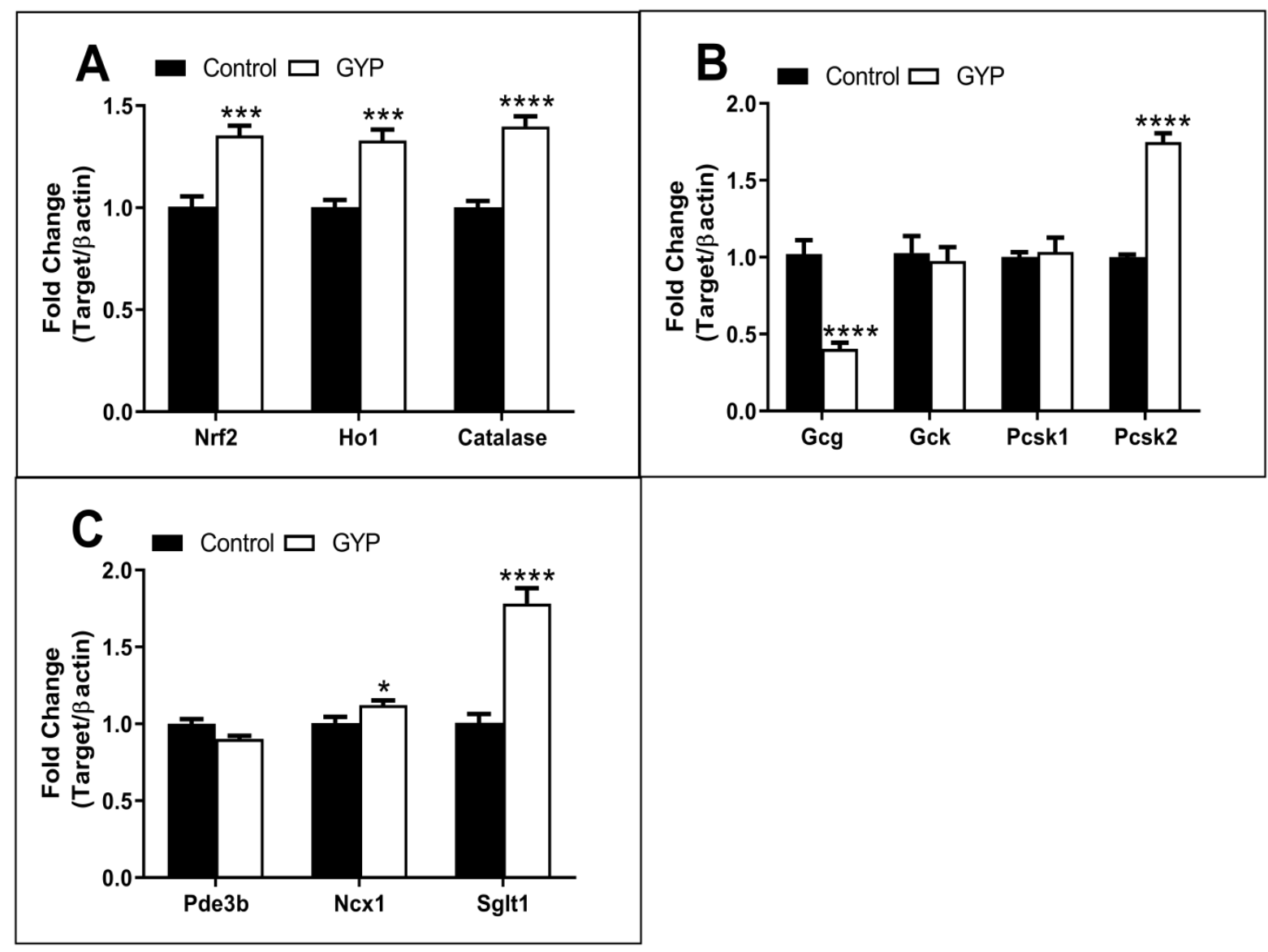

Figure 3: Effects of $24 \mathrm{~h}$ culture with GYP $(100 \mu \mathrm{g} / \mathrm{ml})$ on expression of key genes in GLUTag cell. Data represent fold change in mRNA levels compared to control/untreated GLUTag cell and normalised to $\beta$-actin expression. Values represent mean \pm S.E.M. from three independent experiments performed in duplicate. Student's $t$ test was used for statistical analysis. ${ }^{*}, \mathrm{P}<0.05 ;{ }^{* * *}, \mathrm{P}<0.001 ;{ }^{* * * *}, \mathrm{P}<0.0001$. 


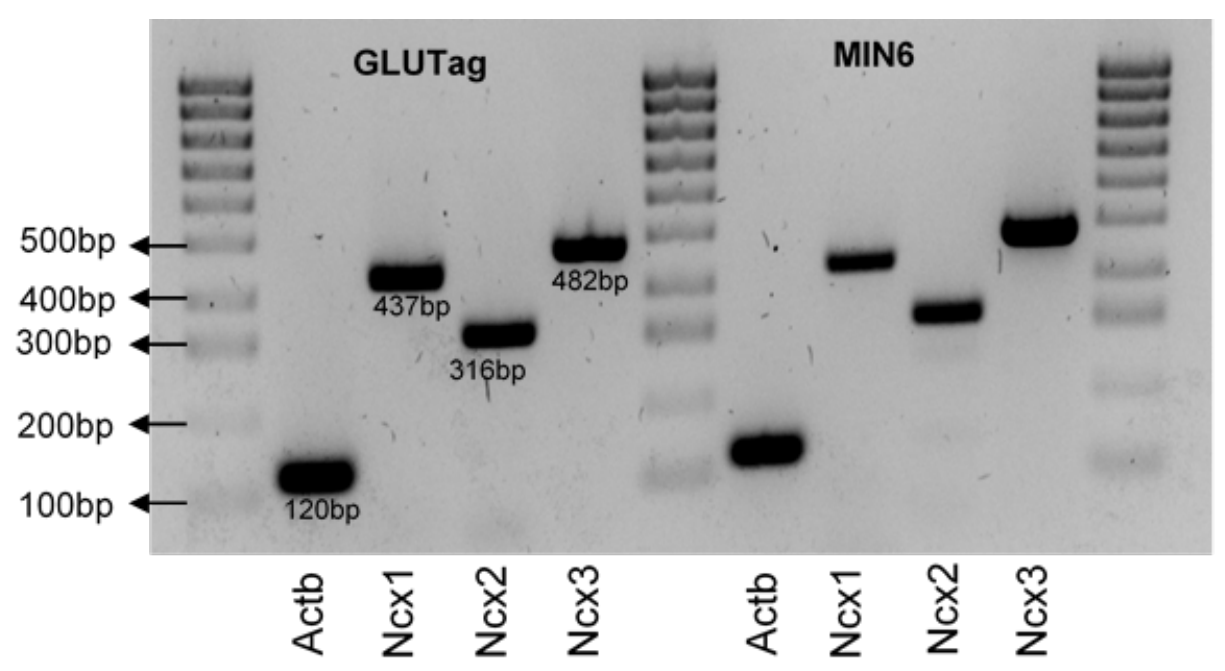

Figure 4: Expression of sodium/calcium exchanger in GLUTag cells and mouse insulinoma MIN6 cells. Amplification of GLUTag mRNA by PCR detected Ncx1, Ncx2 and Ncx3. MIN6 cell mRNA was used as positive control for the primer pairs which are shown on the right. 


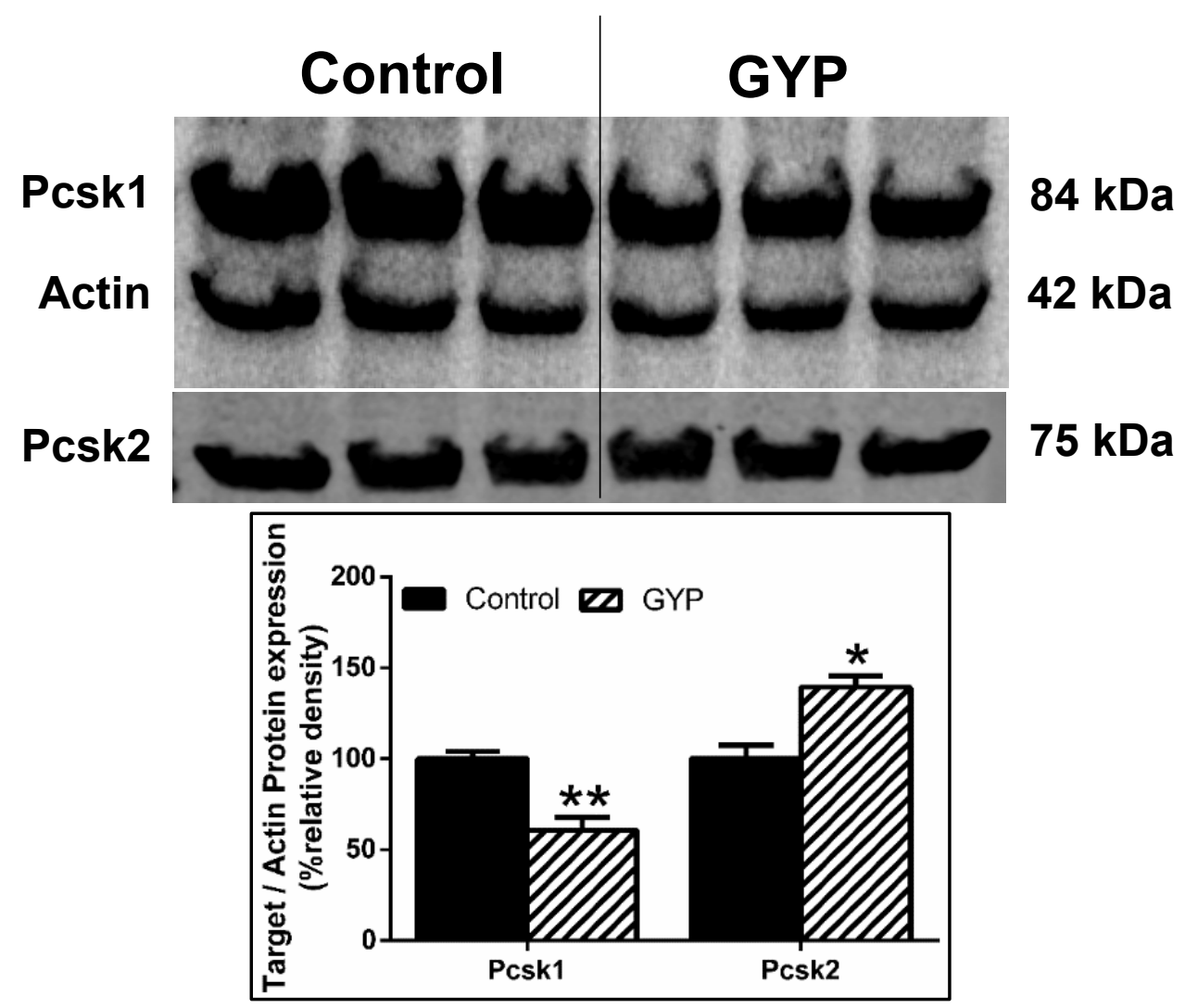

Figure 5: Effects of GYP treatment on Protein expression. Changes in Pcsk1 and Pcsk2 protein expression over $24 \mathrm{~h}$ treatment with GYP normalised to Actin expression. Plotted as \%change to control. Values represent mean \pm S.E.M. from three different experiments. Student's t test was used for statistical analysis. ${ }^{*}, P<0.05$; ${ }^{* *}, \mathrm{P}<0.01$. 


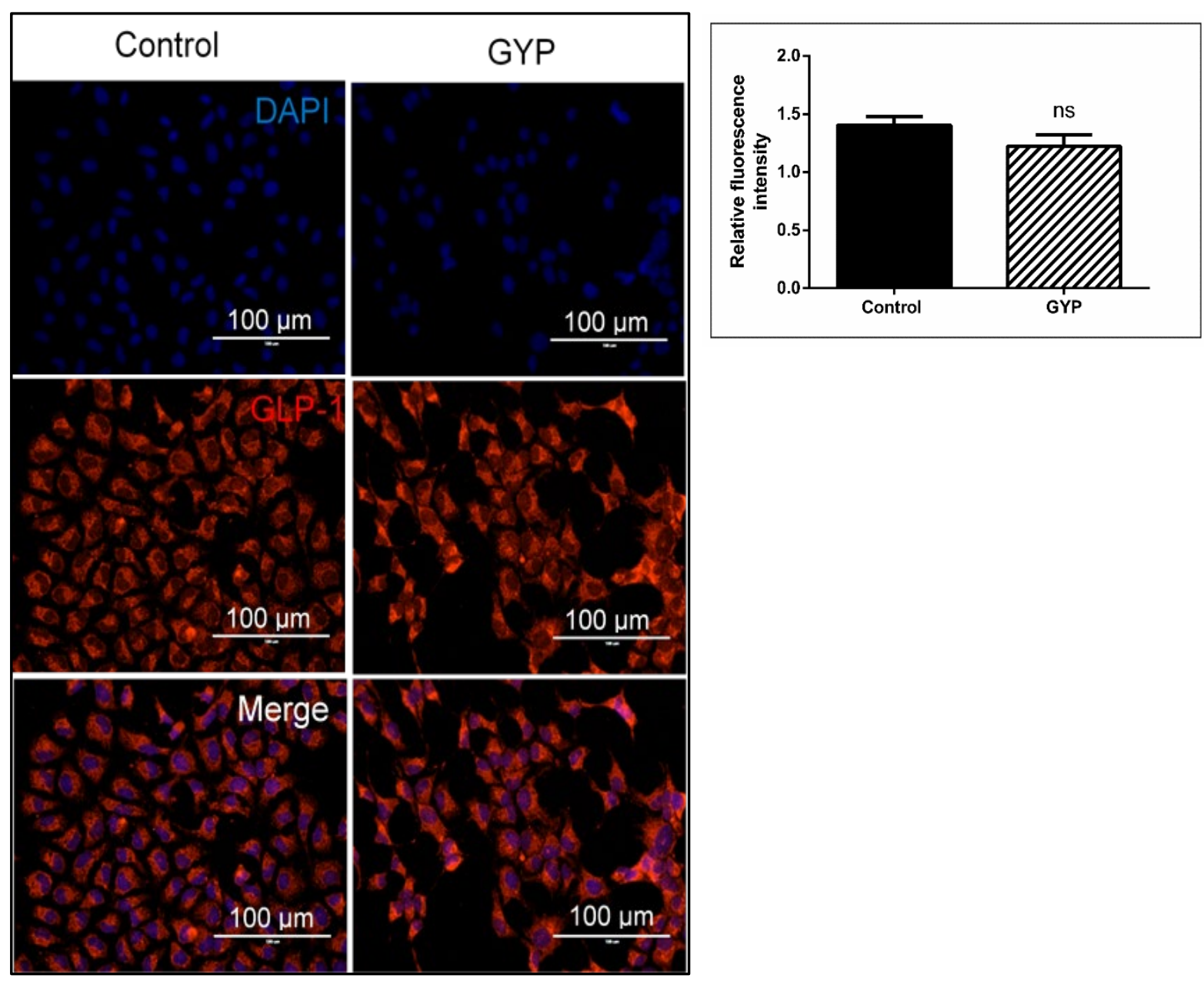

Figure 6: Effects of GYP treatment on GLUTag cellular GLP-1 content. GLUTag cells treated with $100 \mu \mathrm{g} / \mathrm{ml}$ for $24 \mathrm{~h}$ followed by staining with GLP-1 and nuclear stain DAPI. Fluorescence from control and GYP treated cells was measured (100 cells per coverslip from 4 separate experiments) and data was plotted as mean pixel intensity per 1000 pixel ${ }^{2}$. Negative control was used to confirm specific GLP-1 staining and involved omission of primary anti-GLP-1 antibody only - samples without primary antiGLP-1 stained positive for DAPI only. 